\title{
Environmental Factors that influence Supply Chain Management Implementation in the Manufacturing Industries in Kenya: A Case of Manufacturing Industries in Nairobi, Kenya
}

\author{
Stephen Waithaka Titus ${ }^{1}$, Tom Kimani Mburu² ${ }^{2}$ Julius Koror $^{3}$, Stephen Muathe ${ }^{4}$ \\ ${ }^{1}$ Lecturer, Communication and Information Technology Department, Kenyatta University, Nairobi, KENYA \\ ${ }^{2}$ Manager, Training and Programs, Africa Economic Research Consortium, Nairobi, KENYA \\ ${ }^{3}$ Lecturer, Economics Department, Kenyatta University, Nairobi, KENYA \\ ${ }^{4}$ Lecturer, School of Business, Kenyatta University, Nairobi, KENYA
}

\begin{abstract}
The study looked at the factors influencing the implementation of supply chain management in the manufacturing industries in Kenya. The target population was the 52 manufacturing industries in Nairobi. Data was collected using questionnaires and semi-structured interview guide. A logit model was used to draw inferences on the factors influencing the implementation of supply chain management implementation in the manufacturing industries in Kenya. Two factors were found too positively and influence implementation of supply chain management implementation in the manufacturing industries in Kenya, while two other factors we found to hinder the implementation of supply chain management implementation in the manufacturing industries in Kenya.
\end{abstract}

Keywords: Supply chain management systems, SCS Implementation, manufacturing industries in Kenya, Factors influencing implementation

\section{INTRODUCTION}

Supply chain management systems are systems that are used to connect firms together for the purpose of the management of products, materials, information and financial report flows manage. They integrate different sets of operations into a single supra-organization that crosses individual organizations boundaries (Schary, Skjott-Lasen, and Tag, 1995). Supply chain management is applied by companies across the globe due to its demonstrated results such as delivery time reduction, improved financial performance, greater customer satisfaction, building trust among suppliers, and others. According to Ronald, Michael and Rodger (2004) properly implemented, SCM can positively impact many functions and outcomes of the organization including product quality, customer responsiveness and resultant satisfaction, manufacturing cost control, product and market flexibility, and macro performance outcomes including market share. 


\section{Purpose OF ThIS StUdy}

The purpose of this study was to expand the knowledge base regarding the factors that are hindrances to the implementation of supply chain management (SCM) in manufacturing industries in Kenya. Past studies on SCM mainly concentrated on the benefits of the SCM, which included faster orders processing (Sheridan 1999); reduced costs and improved efficiency (Quinn 2000); faster delivery of products and an effective communication (LaLonde and Masters 1994); and a higher profit realization (Timme \& Timme 2000).

Despite These benefits that can be realized in SCM implementation, implementation of SCM is still at infant stages in the manufacturing industries in Kenya (Bolo and Wainaina, 2011). What are not clear are the factors that influence the implementation of SCM in manufacturing industries in Kenya despite the wide range benefits that can be realized by implementing such a technology in industries.

\section{LITERATURE REVIEW}

Kenya's manufacturing sector is going through a major transition period largely due to the structural reform process, which the Kenya Government has been implementing since the mideighties with a view to improving the economic and social environment of the country. Bolo and Wainaina (2011) noted in their study that corporations have increasingly turned to global markets for their supplies, and that the globalization of supply chains has forced companies to look for better and more inter-linked systems between SCM competencies, multiple SCM strategies and the implementation processes and SCM capabilities to coordinate the flow of materials into and out of the company as opposed to the fragmented systems, which have characterized many organizations in Kenya. According to Hugos, M., 2006, a supply chain management is a combination of companies who perform different functions such as producers, distributors or wholesalers, retailers, and companies or individuals who are the customers to the retailers, and are the final consumers of a product. Service providers support these companies to integrate and join a SCM cluster. However, linkages of industries by use of SCM in Kenya are weak and because of this, there exists little inter-industry integration in the country. This has resulted in consistently low manufacturing value added in the sector (KAM 1989).

\section{RESEARCH FrameWORK}

The research framework of the study is shown in Figure 1. From this figure, the dependent variable is SCM implementation. In addition, there are five independent variable namely; Government support, Demand for efficient processes, Cost developing and running SCM, Perceived benefits of SCM implementation and Trust between trading partners.

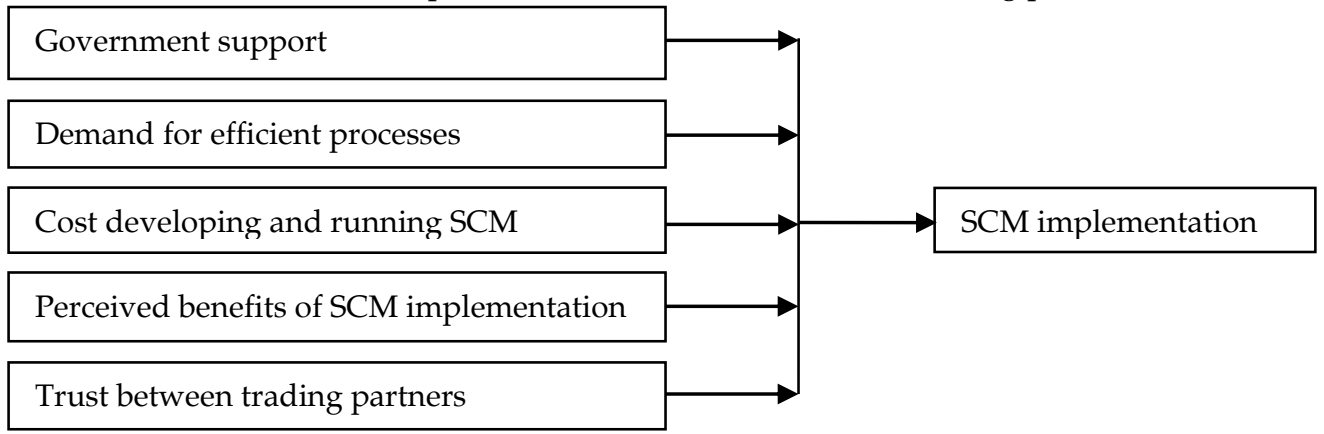

Figure 1: Research framework 


\section{MetHodology}

The study used a combination of cross-sectional descriptive survey and explanatory research design. A descriptive research gives a thorough and accurate description survey by determining the "how" or "why" the phenomena came into being, and also what is involved in the situation (Neuman, 1997). This is achieved by portraying an accurate profile of the events and situations (Robson, 2002), which Sunders et al. (2007) considered as an extension of, or forerunner to an explanatory research.

The determinants of Supply Chain Management in the manufacturing industries in Kenya were determined using the logistic model, also known as logit model. The model calls for the analysis and prediction of a dichotomous outcome. Traditionally, this could have been addressed by either ordinary least squares (OLS) regression or linear discriminant function analysis. However, both techniques were found to pose challenges in handling dichotomous outcome due to their strict statistical assumptions such as linearity, normality and continuity for OLS regression, and multivariate normality with equal variances and covariances for discriminant analysis As such the logit model was found suitable to draw inferences in this study.

\section{Model specification}

$\ln \left[\frac{P_{i}}{1-P_{i}}\right]=Z=X B+u=\beta_{0}+\beta_{1} X_{i 1}+\beta_{2} X_{i 2}+\ldots+\beta_{k} X_{i k}+u_{i}$

Where:

$X_{i 1} \ldots X_{i k i}$ are the explanatory variables

$\beta_{1}-\beta_{\mathrm{k}}$ are the coefficients from the log of the odds ratio function.

$\mu=$ a vector of random terms

\section{Data collection methods}

The study was conducted on the manufacturing industries in Kenya that are members of Kenya Associate of manufacturers (KAM). A questionnaire and a semi-structured interview guide were used to collect data. A questionnaire was developed based on the objectives of the study. The questions were designed to cover general background information of the respondents relating to SCM implementation based on the conceptual framework.

\section{Target population}

The target population was all large private manufacturing entities in Kenya, which are members of Kenya Associate of Manufacturers (KAM) that were operational during the period the study was conducted. These firms were selected since they are considered as being able to provide information on the environmental factors that influence supply chain management implementation in the manufacturing industries in Kenya. Other outside the manufacturing sectors were considered outside the scope of the paper and were considered not being able to reveal substantial data for statistical analysis. 
A survey of 52 large private manufacturing entities in Nairobi, the capital city of Kenya, was carried out using a census of all these firms. This was necessary due to the logit model used for inferential analysis in this study requires a minimum of 50 samples according to Muathe, wawire and Ofafa (2010), hence the 52 manufacturing industries in Nairobi were too few to sample, hence a census was found appropriate in this study.

The independent variables that were used for inferential analysis were environmental factors which were categorized into demand by stakeholders for efficient manufacturing process, Government support, perceived benefits of supply chain management and perceived cost of developing and running a supply chain management system. These factors were operationalized and hypothesized to influence the implementation of supply chain management in the manufacturing industries in Kenya positively, negatively or indefinite as depicted in Table 1.

Table 1: Operationalization and Measurement of Variables and Hypothesis

\begin{tabular}{|c|c|c|c|c|}
\hline Category & Variable Definition & Operationalization & Measure & $\begin{array}{l}\text { Hypothesized } \\
\text { Direction of } \\
\text { the } \\
\text { Variable }\end{array}$ \\
\hline $\begin{array}{l}\text { Dependent } \\
\text { variable }\end{array}$ & $\begin{array}{l}\text { Implementation of } \\
\text { Supply Chain } \\
\text { Management (SCM) in } \\
\text { manufacturing } \\
\text { industries in Kenya (Y) }\end{array}$ & $\begin{array}{l}\text { Development and use of } \\
\text { Supply Chain Management } \\
\text { (SCM) in manufacturing } \\
\text { industries in Kenya }\end{array}$ & $\begin{array}{l}\text { Dummy variable based on the actual } \\
\text { data: } 1 \text { if implemented, otherwise } 0: \text { if } \\
\text { not implemented. . }\end{array}$ & None \\
\hline \multirow[t]{5}{*}{$\begin{array}{l}\text { Environme } \\
\text { ntal factors }\end{array}$} & $\begin{array}{l}\text { Demand by } \\
\text { stakeholders for } \\
\text { efficient } \\
\text { manufacturing process }\end{array}$ & $\begin{array}{l}\text { Demand by stakeholders } \\
\text { for efficient manufacturing } \\
\text { process in Kenya. }\end{array}$ & $\begin{array}{l}\text { Extent to which the demand by } \\
\text { stakeholders for efficient } \\
\text { manufacturing process influences the } \\
\text { implementation of SCM on a } 1-5 \text { scale }\end{array}$ & Positive \\
\hline & $\begin{array}{l}\text { Government support } \\
\text { in the implementation } \\
\text { of SCM in } \\
\text { manufacturing } \\
\text { industries. }\end{array}$ & $\begin{array}{l}\text { Government provision of } \\
\text { financial incentives, pilot } \\
\text { projects, and tax breaks to } \\
\text { stimulate implementation } \\
\text { of SCM in manufacturing } \\
\text { industries in Kenya. }\end{array}$ & $\begin{array}{l}\text { Extent to which the amount of financial } \\
\text { incentives provided by the } \\
\text { government, number of pilot projects } \\
\text { and the amount of tax breaks influences } \\
\text { the implementation of SCM in } \\
\text { manufacturing industries on a } 1-5 \text { scale. }\end{array}$ & Positive \\
\hline & $\begin{array}{l}\text { Perceived benefits of } \\
\text { supply chain } \\
\text { management }\end{array}$ & $\begin{array}{l}\text { Perceived benefits of } \\
\text { supply chain management } \\
\text { stimulates implementation } \\
\text { of SCM in manufacturing } \\
\text { industries in Kenya. }\end{array}$ & $\begin{array}{l}\text { Perceived benefits of supply chain } \\
\text { management stimulates implementation } \\
\text { of SCM in manufacturing industries in } \\
\text { Kenya on a } 1-5 \text { scale. }\end{array}$ & Positive \\
\hline & $\begin{array}{l}\text { Trust between trading } \\
\text { partners to join SCM }\end{array}$ & $\begin{array}{l}\text { Trust between trading } \\
\text { partners to join SCM } \\
\text { stimulates implementation } \\
\text { of SCM in manufacturing } \\
\text { industries in Kenya. }\end{array}$ & $\begin{array}{l}\text { Trust between trading partners to join } \\
\text { SCM stimulates implementation of SCM } \\
\text { in manufacturing industries in Kenya on } \\
\text { a 1-5 scale. }\end{array}$ & Positive \\
\hline & $\begin{array}{l}\text { Perceived cost of } \\
\text { developing and } \\
\text { running a supply } \\
\text { chain management } \\
\text { system. }\end{array}$ & $\begin{array}{l}\text { Perceived cost of } \\
\text { developing and running a } \\
\text { supply chain management } \\
\text { system. }\end{array}$ & $\begin{array}{l}\text { Perceived cost of developing and } \\
\text { running a supply chain management } \\
\text { system stimulates implementation of } \\
\text { SCM in manufacturing industries in } \\
\text { Kenya on a 1-5 scale. }\end{array}$ & Positive \\
\hline
\end{tabular}

\section{Data Collection Procedure}

Data was collected over a period of one month. First, the researcher sought permission from the target manufacturing industries to collect data. Afterwards, the researcher sought appointments with the managers of the firms that granted the researcher permission to collect data, after which the research assistants proceeded to self-administer questionnaires to the managers and staff involved in the supply chain management transactions in the industries, under the supervision of the researcher. The researcher 
administered the interviews to the managers and the staff of these industries. The interviews were audio-taped and transcribed to ensure that the data was collected and used accurately.

After collecting data, it was edited to check for completeness, consistency and reliability. Afterwards, the data was transferred to the STATA for analysis.

\section{Results AND Discussions}

A total of 52 questionnaires were administered to the manufacturing industries in Nairobi. 36 these questionnaires were filled and returned. This resulted to a response rate of $69 \%$, which compares well with the response rate of 46 per cent recommended by Sheehan (2001). The study therefore considered the response rate sufficient to be used to draw inferences in the environmental factors that influence the implementation of supply chain management in the manufacturing industries in Kenya.

\section{The regression result}

A binomial logit model was estimated the explanatory variables considered in this study. In the model, the implementation of the Supply Chain Management (SCS )was the dependent variable that took the value of one (1) if Supply Chain Management was implemented in a firm and zero (0) if IOIS was not implemented in a firm. The explanatory variables that were considered included demand by stakeholders for efficient manufacturing process, Government support in the implementation of Supply Chain Management in manufacturing industries, perceived benefits of supply chain management, Trust between trading partners needed to join Supply Chain Management and Perceived cost of developing and running a supply chain management system. The results of the logistic regression are presented in Table 2.

Table 2 Logit Regression Results

\begin{tabular}{|c|c|c|c|c|c|c|}
\hline Variable & Coefficient & Std. error & $\mathbf{Z}$ & $P>|Z|$ & 95\% coefficient & Interval \\
\hline Demand & $5.4103^{* *}$ & 2.3363 & -2.32 & 0.021 & -9.9894 & -0.83129 \\
\hline $\begin{array}{l}\text { Government } \\
\text { support }\end{array}$ & $-0.20766^{* *}$ & 0.9661 & 2.15 & 0.032 & -0.01831 & 0.39701 \\
\hline Cost & $-1.0321^{* * *}$ & 0.38973 & -2.65 & 0.008 & -1.79588 & -0.26813 \\
\hline Benefits & $0.24192^{* *}$ & 0.10990 & 2.07 & 0.028 & 0.02652 & 0.45733 \\
\hline Trust & -0.33571 & 0.151576 & 2.21 & 0.427 & 0.03864 & 0.63277 \\
\hline \multicolumn{3}{|c|}{$\begin{array}{l}\text { Number of observations ................. } 36 \\
\text { Probability }>\text { Chi ......................0.0001 }\end{array}$} & \multicolumn{4}{|c|}{$\begin{array}{l}\text { LR Chi squared (11) ...................4.4.31 } \\
\text { Pseudo } R^{2} \ldots \ldots \ldots \ldots \ldots \ldots \ldots \ldots .7307\end{array}$} \\
\hline
\end{tabular}

From Table 2, Log Likelihood (LR) test gave a value of 42.31 which was statistically significant at $1 \%$ level. This implies that the overall logit model that was estimated was statistically significant, that is, there was a significant relationship between the log of odds ratio and the explanatory variables.

From Table 2, the Pseudo $\mathrm{R}$ squared of the regression was 0.73, which implies that the included variables explained only 73 per cent of the variations in the implementation of Supply Chain Management among the manufacturing industries studied. The remaining 27 per cent was explained by other explanatory variables not included in the model.

Similarly, two explanatory variables namely demand by stakeholders for efficient manufacturing process, perceived benefits of SCM had the expected positive signs that were statistically significant at 5 per cent level of significance. However, the perceived cost of 
developing and running a supply chain management system variable had the expected negative sign that was statistically significant at 5 per cent level of significance. In addition, two explanatory variables namely Government supports in the implementation of SCM and Perceived benefits of supply chain management did not have the expected positive signs but negative signs and were statically significant at 5 per cent level of significance. One variable, trust between trading partners to join SCM, did not have the expected positive signs but negative signs, and was not statistically significant at 5 per cent or 10 per cent levels of significance. The influence of these variables in SCM implementation of discussed as follows:

Government support: This variable had a negative coefficient but statistically significant at 5 per cent level of significant. This implies that there is lack of Government support to encourage manufacturing industries in Kenya to implement the supply chain management systems in their processes. Therefore, the higher the lack of government supports, the lower the levels of supply chain management implementation in manufacturing industries in Kenya. These findings are contrary to the findings of Elzarka, Tipi, Hubbard and Bamford (2012) who found out that the level of support that the company receives from the government when importing raw materials or products from overseas or using domestic materials, which includes the use of norms, regulations, policies, and advice for the manufacturing sector encourages firms to adopt supply chain management. They also noted that when governments make a series of reforms by increasing manufacturing sector's competitiveness in the international market through logistics competency, it encourages manufacturers to initiate supply chain management systems.

Trust between trading partners: The coefficient of trust between trading partners was negative and not significant at 5 per cent or 10 per cent level of significant. This pointed to the facts that trust between trading partners is not an important determinant of supply chain management systems in the manufacturing industries in Kenya. This could be attributed to the fact that trust relationships between the firms could have been established before the firms became trading partners, As such, another trust relationship with therefore not be necessary since there was one already in existence. These findings are different from the finding of $\mathrm{Li}$, Rao, Ragu-Nathan, Ragu-Nathan (2005) who postulated that the supply chain trust relationships play an important role in achieving the firm's supply chain management goals and is directly related to relationship management, which includes suppliers and customers.

Perceived benefits of supply chain management systems: Perceived benefits of supply chain management systems variable had a positive coefficient that was significant at 5 per level of significant. This meant that the firms that perceived the supply chain management systems as being beneficial them were more likely to implement the supply chain management systems than the firms that do not perceived the supply chain management systems as being beneficial them. These findings are in agreement with the findings of Fraza (2000), who found out that the coordination and integration of activities with suppliers and understanding of customer's needs results in greater benefits for companies.

Perceived cost of developing and running supply chain management systems: Perceived cost of developing and running supply chain management systems variable had a negative coefficient that was significant at 1 per level of significant. This meant that the firms that perceived the cost of developing and running supply chain management systems as being high were less likely to implement the supply chain management systems than the firms that do not perceived the cost of developing and running supply chain management systems as being high. 


\section{CONCLUSION}

Further, the study found out that there exits low levels implementations of the supply chain management systems in the manufacturing industries in Kenya. This could be attributed to the fact that the Government of Kenya has not the necessary policies and measures in place to ensure that the manufacturing industries in Kenya are given the necessary support to encourage them to implement the supply chain management systems in the industries.

Two factors were found to encourage the implementation of supply chain management systems in the manufacturing industries in Kenya. These factors were demand by stakeholders for efficient manufacturing process and the perceived benefits of supply chain management systems in the manufacturing industries. In addition, two factors were found to hinder the implementation of supply chain management systems in the manufacturing industries in Kenya. These factors were Government support to encourage manufacturing industries in Kenya to implement the supply chain management systems in their processes and the perceived cost of developing and running supply chain management systems in the manufacturing industries. However, trust between the trading partners factor was found to be unimportant factor in influencing manufacturing industries in Kenya to implement supply chain management systems.

The study recommended that the government provide financial incentives, pilot projects and tax breaks to stimulate implementation of SCM in manufacturing industries in Kenya. In addition, the government should lower the tax of all the facilities necessary in the development of the supply chain management to make the implementation affordable by the manufacturing industries.

\section{ACKNOWLEDGEMENT}

We wish to acknowledge the support of different manufacturing companies for providing the necessary technical support that was required in this research work. We acknowledge the support of Ms Gladys Kimutai and Ms Lucy Kamau from Kenyatta University everybody else who gave us both moral and financial support to complete this work. We recognize your support and participation.

\section{REFERENCES}

Bolo A. Z and Wainana G. (2011). An Empirical Investigation of Supply Chain Management Best Practices in Large Private Manufacturing Firms in Kenya. Prime Journal of Business Administration and Management Volume 1, Issue 2, 2-3.

Elzarka S, Tipi N, Hubbard N, Bamford C. Creating a Logistics Competency Framework for Egyptian Clothing Companies. SSRN Working Paper Series (2011).

Fraza V. (200). SCM for small distributors. Industrial Distribution (2000) 89:81.

Hugos, M., (2006), Essentials of Supply Chain Management. Hermeneutics, Routledge encyclopaedia of philosophy, Routledge, London, p. 384-389.

Kenya Association of Manufacturers (1989) Edition Directory, Export Incentives for Kenyan industry.

Li S, Rao SS, Ragu-Nathan TS, Ragu-Nathan B. (2005), Development and validation of a measurement instrument for studying supply chain management practices. Journal of Operations Management (2005) Vol 23, 6-18

Muathe S.M.A, Wawire H. Wand Ofafa G. (2010). Determinants of adoption of ICT by Small and Medium Enterprices (SME) within the health sector in Nairobi, Kenya. Unpublished PhD theses. 
Neuman, W.L. (1997).Social research methods: Quantitive and qualitative approaches. $3^{\text {rd }}$ edition, Boston, Mass, Allyn and Bacon, pp. 20-29.

Robson, C. (2002). Real world research ( $2^{\text {nd }}$ edn), Oxford, Blackwell.

Ronald L. M.., Michael R. W., and Rodger B. S. (2004) [Supply Chain Management: Strategic Factors From The Buyers' Perspective. Journal of Industrial Technology, Volume 20, Number $2,2$.

Schary P., Skjott B. and Tag L. (1995). Managing the glabal supply chain management, Copenhagen business school press, Copenhagen.

Sheehan K. (2001). E-mail Survey Response Rates: A Review. School of Journalism and Communication, University of Oregon. JMC 6 (2) January 2001.

Timme, S. G. \& Timme, C. W. (2000). The Financial SCM Connection. Supply Chain Management Review. Vol. 4, No. 4, 32-40.

\section{ABC-JAR!!!}

"Speedy publication service, Online archives, Paperless, web-based peer review system, Open access policy, Indexing in world known citation databases, Global circulation, Broad international readership and authorship, Online submission system, Minimum publication charge" 